\title{
Monitoring Human Activities in the Tamoios Ecological Station - Rio de Janeiro: Management Challenges
}

\author{
Carolina Delfante de Pádua Cardoso \\ Rosa Maria Formiga-Johnsson \\ Régis Pinto de Lima \\ Rodrigo de Oliveira Campos
}

Ph.D from Postgraduate Program in Environment at the State University of Rio de Janeiro (UERJ). Rio de Janeiro/RJ. Brazil.

${ }^{I I}$ Associate Professor in the Department of Environmental and Sanitary Engineering (DESMA) at the State University of Rio de Janeiro (UERJ). Rio de Janeiro/ RJ. Brazil.

III Ph.D in Oceanography from Federal University of Pernambuco. Environment Analyst from ICMBio. Rio de Janeiro/RJ. Brazil.

${ }^{I V}$ M.Sc. in Fisheries Engineering from University of Ceará (UFC), Research Director at HSDATA Analytics - Data Science and Environmental Projects Ltda. Rio de Janeiro/RJ. Brazil.

\begin{abstract}
This study aimed to understand the dynamics of anthropic uses in the marine protected area of the Tamoios Ecological Station (ESEC Tamoios), in order to provide subsidies for management and mitigation of conflicts. This work performed an exploratory application of single factor analysis of variance models pertaining to records of human activities obtained through 330 monitoring campaigns carried out between 2008 and 2016, specifically data sets on tourism, traffic and fishing uses. Understanding the spatial and temporal distribution of human activities as well as the intensity of their occurrence allowed us to indicate the most conflicting areas of the ESEC Tamoios and priorities for strengthening management. It was concluded that more agreement measures were needed for traditional activities such as small-scale fishing and other management measures for activities highly incompatible with ESEC to be agreed upon between the stakeholders.
\end{abstract}

Keywords: Marine Protected Areas. Anthropic Uses. Social and environmental conflicts

São Paulo. Vol. 23, 2020

Original Article

DOI: http://dx.doi.org/10.1590/1809-4422asoc20190112r2vu2020L5AO 


\section{Introduction}

Human activities continue on an unstoppable growth path into marine and coastal ecosystems. Around the world, these environments are suffering rapid alterations, degradation and losses in biodiversity and their ecosystem functions (MURRAY et al., 2015; JONES et al., 2018). No marine space in the world is free from humans' influence (STACHOWITSCH, 2003; HALPERN et al., 2008a). In this regard, marine protected areas (MPAs) are recognized as one of the most efficient instruments to cope with the increasingly predatory exploitation of marine resources and the degradation of marine and coastal habitats (ANGULO-VALDÉS; HATCHER, 2010; AGARDY et al., 2003; EDGAR et al., 2014). Permissions in such areas can vary from more restrictive uses ("no take areas") to multiple uses, which seek to accommodate different user groups. Many uses can be made without any adverse impacts on their ecosystem function provided there is adequate planning and management in place (AGARDY, 2000).

However, it is important to highlight the social impacts frequently entailed by the creation of Conservation Units (CU) with restrictive use, as discussed by several authors; particularly those related to barring the public from the land and water and the varying uses made around the protected areas (DIEGUES, 2001; JOVENTINO, 2013; DE FREITAS, 2014; SEIXAS et al., 2017; VALLEJO, 2017). Indeed, forbidding the use of a CU's spaces and resources can provoke socio-environmental conflicts related to human activities - traditional or not - taking place in the given territory.

Socio-environmental conflicts can be rooted in perceived threats to a given group's ways of appropriating, using and attributing meaning to a territory by other groups, leading to a dispute or tension between the different groups or social actors (VIVACQUA; VIEIRA, 2005; ACSELRAD, 2010). In the case of CUs, several factors aggravate such conflicts including insufficient criteria to clearly define these protected areas or lacking participation of most of the interested parties in the corresponding creation and management processes (PEREIRA, 2005).

This study focuses on the Tamoios Ecological Station (ESEC for its abbreviation in Portuguese), a predominantly marine CU in the Bay of Ilha Grande, State of Rio de Janeiro, created in 1990 (BRASIL, 1990) as part of the legal requirement to monitor nuclear reactors in that bay (BRASIL, 1980). Its category - Full Protection - is extremely restrictive; legally, no public use is allowed except those related to scientific research and visits for educational purposes (BRASIL, 2000). Yet, as occurs in most MPAs (ASSIS, 2011; ZAPPES, 2011; LOPES et al., 2015), human activities not provided for in this category still take place within this ESEC's boundaries. The conflicts stemming from these uses are the greatest obstacle to effectively managing this area.

The great intensity and diversity of human activities in this region can be attributed to the peculiar natural beauty of the Bay of Ilha Grande, which is recognized as a hotspot for its relevant biodiversity and is considered a priority area for the conservation of coastal and marine areas (CREED et al., 2007; MMA, 2018). In the beginning of 2019, the Tamoios ESEC was featured prevalently in Brazilian media due to statements made by Brazil's president indicating that rules related to its preservation would be relaxed or 
altogether extinguished (SASSINE, 2019) with the intention of turning the Bay of Ilha Grande into a "Brazilian Cancun" (ALTINO, 2019).

This study takes place within this context of rising pressure on the Bay of Ilha Grande and the Tamoios ESEC, aiming to fill in gaps regarding the overall knowledge of human activities taking place within this territory. Understanding the spatial distribution and intensity of human activities in CUs is considered essential to effectively manage and conserve oceans (CRAIN et al., 2008; HALPERN et al., 2008b; PARRAVICINI, 2012), and to identify, address and mitigate existing socio-environmental conflicts.

Many studies have addressed the ecological and ecosystemic aspects of this ESEC and the Bay of Ilha Grande (TEIXEIRA-NEVES et al., 2015; CREED et al., 2016; ROCHA et al., 2016; CREED et al., 2017), in addition to conflicts involving traditional communities that practice artisanal fishing (JOVENTINO, 2013; LOPES et al., 2013, 2015; DE FREITAS, 2014; SEIXAS et al., 2017; JOVENTINO; FORMIGA-JOHNSSON, 2018; DIAS; SEIXAS, 2019). However, the authors did not identify any studies providing a broad overview of the human activities occurring in the CU territory, as proposed herein.

This article's main objective is to understand the conflicts in the Tamoios ESEC based on an analysis of extensive monitoring of human activities in this area. In this way, it hopes to provide useful information for the effective management of the CU and the Bay of Ilha Grande, as well as valuable reflections on the use dynamics in MPAs.

\section{Methods}

Data from the Tamoios ESEC was used to analyze the human activities that take place in the CU's area. This data has been collected since 2008 by the Chico Mendes Institute for Biodiversity Conservation (ICMBio), a federal organization responsible for managing the CU. The ICMBio performs routine periodical monitoring of such activities in order to register, identify, understand, inform and promote awareness to users (ICMBio, 2009). The ESEC only provided monitoring data; the authors prepared all working documents including spreadsheets, the data matrix structure, a categorization of activities, groupings of islands, a definition of time-related data and the final analysis.

The Tamoios ESEC is located on the southern Fluminense coast in the Bay of Ilha Grande, encompassing two municipalities: Angra dos Reis and Paraty. It comprises 29 islands, rocks and marine slabs, as well as the marine area within $1 \mathrm{~km}$ of the islands' land borders. Of this entire makeup, almost $97 \%$ of this zone is marine area.

The ICMBio team of the Tamoios ESEC monitors human activities; the authors participated in a number of reconnaissance missions to assess the area and the adopted methods. The data provided for this study come from collection efforts performed between the years 2008 and 2016, encompassing 330 campaigns and 1,320 hours in the field.

Monitoring was performed weekly and consisted in an approximately 4-hour route aboard a speedboat. Every week, monitoring was performed in an area corresponding with one of the ESEC's municipalities (Angra dos Reis or Paraty); the marine surroundings of every island were toured in circles registering any human activities (ICMBio, 2009). 
Such monitoring techniques are unique given their survey efforts, the scope of the area under examination, the time spent and their frequency. The sample distribution was different over the years owing to operational matters. However, the difference in the temporal samples'distribution did not impact the findings as trimestral averages were used to balance the samples in time blocks. Carrying out this technique was not possible for the few data series from 2010, due to which that data was not included in the analysis of variance models.

\section{Categorization of human activities}

In light of the considerable diversity of activities registered, this study created its own categorization based on the activity type (Table 1).

Table 1 - Categorization of human activities

\begin{tabular}{|c|c|c|}
\hline & Activities & Categories \\
\hline 1 & Jet-Ski & \multirow{9}{*}{ Tourism, recreation and water sport } \\
\hline 2 & Surf & \\
\hline 3 & Canoeing / kayak & \\
\hline 4 & Swimming & \\
\hline 5 & Diving & \\
\hline 6 & Anchored scuba diving vessel & \\
\hline 7 & Number of divers* & \\
\hline 8 & Anchored leisure vessel & \\
\hline 9 & Anchored touring vessel & \\
\hline 10 & Passing vessel & Traffic \\
\hline 11 & Anchored fishing vessel & \multirow{12}{*}{ Fishing } \\
\hline 12 & Angling vessel & \\
\hline 13 & Number of fishermen* & \\
\hline 14 & Gillnet vessel & \\
\hline 15 & Trawling vessel & \\
\hline 16 & Purse-seine vessel & \\
\hline 17 & Tuna fishing vessels & \\
\hline 18 & Gillnet & \\
\hline 19 & $\begin{array}{l}\text { Fishing on the continent (ESEC } \\
\text { areas adjacent to the continent) }\end{array}$ & \\
\hline 20 & Spearfishing & \\
\hline 21 & $\begin{array}{l}\text { Artisanal fixed fish-trap ("cercofi- } \\
\text { xo") }\end{array}$ & \\
\hline 22 & Trap fishery ("covo") & \\
\hline
\end{tabular}

Source: Authors' elaboration, 2019.

*This activity is related to the previous activity 
Regarding the CU's spatial layout, its 29 islands were assembled into groups based on their proximity and/or overlapping marine areas, taking the block groupings proposed by the CU's own Management Plan (IBAMA, 2000) taken as a reference. In this way, the islands were divided into a total of 8 groups (see Figure 1).

Furthermore, the islands were grouped into 3 distance classes (D1 $<1 \mathrm{~km}$; D2 $>$ $1 \mathrm{~km}$ and $<3 \mathrm{~km}$; and D3 $>3 \mathrm{~km}$ ) to assess if the distance between the ESEC's islands and the continent influenced the occurrence of human activities.

\section{Analysis of monitoring data}

The data collected and provided to the authors by the ICMBio were inserted in electronic spreadsheets (Microsoft Office Excel ${ }^{\circledR}$ ) and organized in a matrix structure, or framework, for statistical analysis in the program R (R Core Team, 2016).

The initial analyses were carried out by applying typical descriptive statistical methods (QUINN; KEOUGH, 2002), driven by a formal exploratory data analysis approach (TUKEY, 1977). The data was examined as a whole in light of possible patterns related to space (i.e. island groupings, distances from coast) and time (i.e. year, trimester). These analyses were depicted in diagrams such as histograms and boxplots (TUKEY, 1977; QUINN; KEOUGH, 2002).

The average trimestral values were used in the application of ANOVA models. This approach was required to balance the samples given the asymmetry in the sample size from one year to another and to obtain more homogeneous variance. Thus, 3 cycles of such models were performed using single or one-way ANOVA with the following response variables to represent the detected human activities: (i) fishing activity; (ii) tourism, recreation and sport activity; and (iii) vessel traffic. The total of all registered activities was also used as an alternative overall response variable.

The data on the occurrence of human activities was mapped using the software ArcGIS 10.3 (ESRI). The data were associated to the polygons of each of the ESEC's islands, georeferencing the data and depicting it on the thematic map.

Finally, the human activities were categorized to assess the main anthropic uses observed in the ESEC Tamoios (clarified in Table 2) as follows: (i) the predominant place of the activity's occurrence; (ii) degree of the activity's incompatibility with the ESEC, based on the assessment of potential impacts generated by the activity in question (CARDOSO, 2019); and (iii) the intensity of the occurrence, based on the distribution of the number of such activities observed on each island (CARDOSO, 2019).

\section{Results}

Among all of the occurrences registered, those uses related to the category of tourism were the most predominant regarding frequency of occurrence (54\%). Registered activities of the vessel traffic category were similar (25\%) to those related to the fishing category (21\%). The most common types of activities were those related to vessels: (i) 
anchored leisure, (ii) passing vessels, (iii) tourism, (iv) line fishing and (v) anchored fishing. The map in Figure 1 depicts the proportion of categories (tourism, traffic and fishing) of human activities observed in each island.

\section{Spatial distribution of uses in the ESEC}

A spatial assessment of the factor "area" (t-test) allowed the authors to conclude that there is no difference in the human uses of the ESEC between the areas of Angra and Paraty $(\mathrm{p}>0.05)$.

The analysis of the distribution of the total number of occurrences of human activities registered per field campaign revealed the highest median value of eight in the island of Catimbau (Figure 2). Intermediate median values of three activities per island were registered in the islands Araçatiba de Dentro, Ilha Comprida, Sandri and Tucum. In the remaining islands, these values varied between one and two (Figure 2). In general, most of islands showed an asymmetric positive distribution, with some cases of several outliers. 
Figure 1: Map of human activity categories (\%) per island in the Tamoios ESEC (2008-2016)

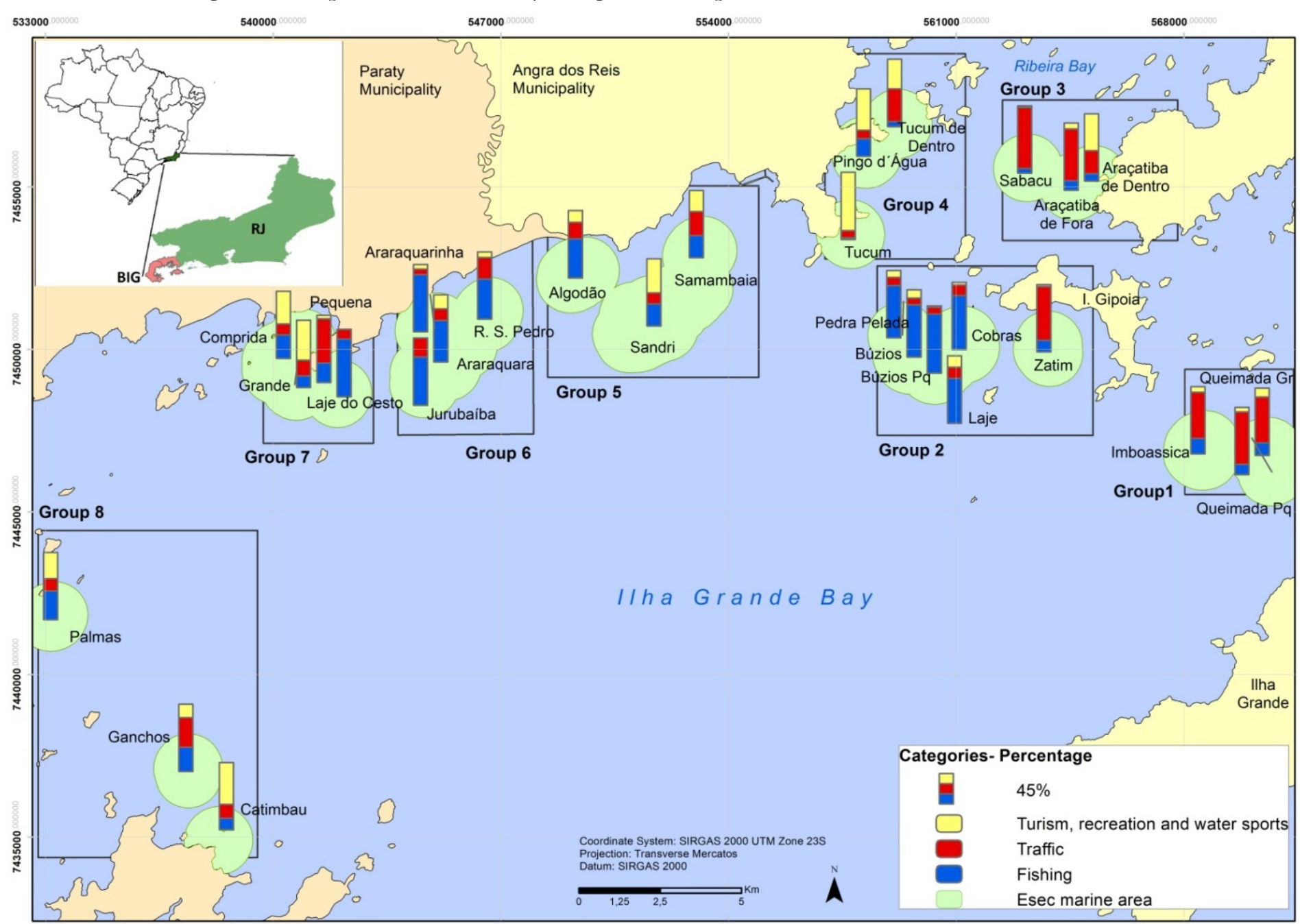


Figure 2 - Distribution of the number of activities observed per island of the ESEC
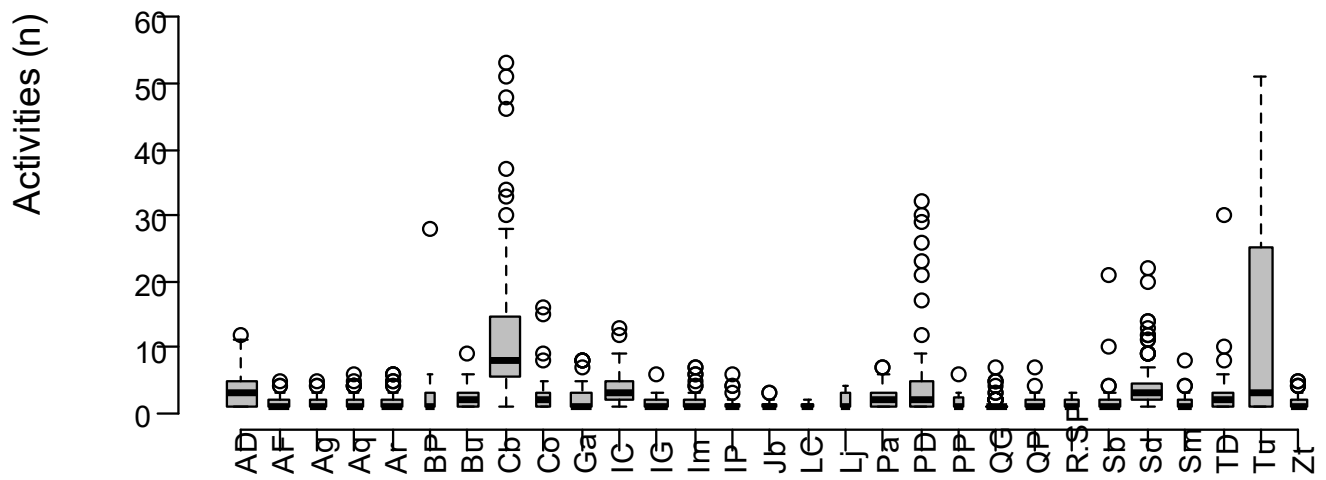

\section{Islands}

Source: Authors' elaboration, 2019.

Legend: $\mathrm{AD}=$ Araçatiba de Dentro, $\mathrm{AF}=$ Araçatiba de Fora, $\mathrm{Ag}=$ Algodão, $\mathbf{A q}=$ Araraquarinha,Ar $=$ Araraquara, $\mathbf{B P}=$ BúziosPequena, $\mathbf{B u}=$ Búzios, $\mathbf{C b}=$ Catimbau,Co $=$ Cobras, $\mathbf{G a}=$ Ganchos, $\mathbf{I C}=$ IlhaComprida, IG = Ilhota Grande, Im = Imboassica, IP = Ilhota Pequena, Jb = Jurubaíba, LC = Laje do Cesto, $\mathbf{L} \mathbf{j}=$ Laje, $\mathbf{P a}=$ Palmas, $\mathrm{PD}=$ Pingo d'Agua, $\mathbf{P P}=$ PedraPelada, $\mathrm{QG}=$ Queimada Grande, $\mathrm{QP}=$ Queimada Pequena, R.SP = Rochedo de São Pedro,Sb = Sabacu, Sd = Sandri,Sm $=$ Samambaia,TD $=$ Tucum de Dentro, $\mathrm{Tu}=$ Tucum, $\mathrm{Zt}=$ Zatin.

Analyzed separately, notable variations can be appreciated among the activities depending on their location. The registry of anchored leisure vessels was greater in the island of Tucum, reaching up to twenty registered vessels in a single monitoring mission. The greatest numbers of anchored tourism vessels were registered in the islands Catimbau and Araçatiba de Dentro, while the number of passing vessels was greater in the island Catimbau.

In reference to activities related to the fishing category, the greatest numbers of occurrences were registered in the islands Cobras, Búzios, Sandri, Ilha Comprida and Catimbau.

A difference can be appreciated in the spatial distribution of the groups when considering all activities $(\mathrm{p}<0.05)$, with group 8 (Catimbau, Palmas and Ganchos) presenting the highest mean value (average $=6$ ). This is mainly associated with the activities related to the categories of tourism and traffic, which also vary between the groups $(\mathrm{p}<0.05)$, the highest values of which are in group 8 . Fishing activities did not present a variation that could be explained by the islands' groupings ( $p>0.05$ ),

The ANOVA model considering the full spectrum of activities as a response variable (overall), indicated the significant influence of differing distances from the coast $(\mathrm{p}<0.05)$. Namely, a greater concentration of anthropic activities occurred in islands closer to the continent (distance D1). Activities related to tourism and vessel traffic were those which 
occurred most close to a coast $(\mathrm{p}<0.05)$, while fishing activities did not vary significantly depending on distance $(\mathrm{p}>0.05)$ despite a notable increase in D3 distance.

The most critical areas in the ESEC regarding the number of registered activities are the islands Catimbau, Tucum, Sandri, Pingo d'Água, Araçatiba de Dentro and Ilha Comprida, among which the value intervals ranged from 385 activities to 1,620. Fewer occurrences were registered in rocky formations (Pedra Pelada, Zatim, Laje, Laje do Cesto and Rochedo São Pedro) as well as the islands Búzios Pequeno, Jurubaíba, Ilhote Pequeno and Samambaia, varying between 30 and 69 activities registered in the entire sample period (2008 to 2016).

Table 2 contains a synthesis of the main human activities registered in the Tamoios ESEC.

Table 2 - Description of the main anthropic uses within the Tamoios ESEC

\begin{tabular}{|c|c|c|c|c|}
\hline $\begin{array}{l}\text { Human activi- } \\
\text { ties }\end{array}$ & $\begin{array}{l}\text { Predominant } \\
\text { location }\end{array}$ & $\begin{array}{c}\text { Level of in- } \\
\text { compatibility } \\
\text { with the ESEC }\end{array}$ & $\begin{array}{c}\text { Frequency of } \\
\text { occurrence }\end{array}$ & Observations \\
\hline Vessel traffic & $\begin{array}{l}\text { Catimbau and } \\
\text { Araçatiba de } \\
\text { Dentro }\end{array}$ & - & Medium & $\begin{array}{l}\text { Activity sanctioned } \\
\text { within the ESEC, low } \\
\text { impact, but the high } \\
\text { level of occurrences } \\
\text { could entail conflict } \\
\text { related to this use } \\
\text { and its impacts on the } \\
\text { ecosystem. }\end{array}$ \\
\hline $\begin{array}{l}\text { Anchoring } \\
\text { fishing vessels }\end{array}$ & $\begin{array}{l}\text { Sandri, Catim- } \\
\text { bau and Buzios }\end{array}$ & Low & Low & $\begin{array}{l}\text { Activity traditionally } \\
\text { occurring within the } \\
\text { ESEC, but despite } \\
\text { not being allowed it } \\
\text { occurs in low density } \\
\text { and does not present a } \\
\text { significant impact }\end{array}$ \\
\hline Fishing & $\begin{array}{l}\text { Cobras, Búzios, } \\
\text { Sandri and Iha } \\
\text { Comprida }\end{array}$ & $\begin{array}{l}\text { Medium and } \\
\text { High }\end{array}$ & Low & $\begin{array}{l}\text { Artisanal fishing: loss } \\
\text { of fishing areas for tra- } \\
\text { ditional communities } \\
\text { entailing social dama- } \\
\text { ges that management } \\
\text { should mitigate. } \\
\text { Industrial fishing: } \\
\text { activity with greater } \\
\text { potential impact and } \\
\text { no potential compati- } \\
\text { bility. }\end{array}$ \\
\hline
\end{tabular}




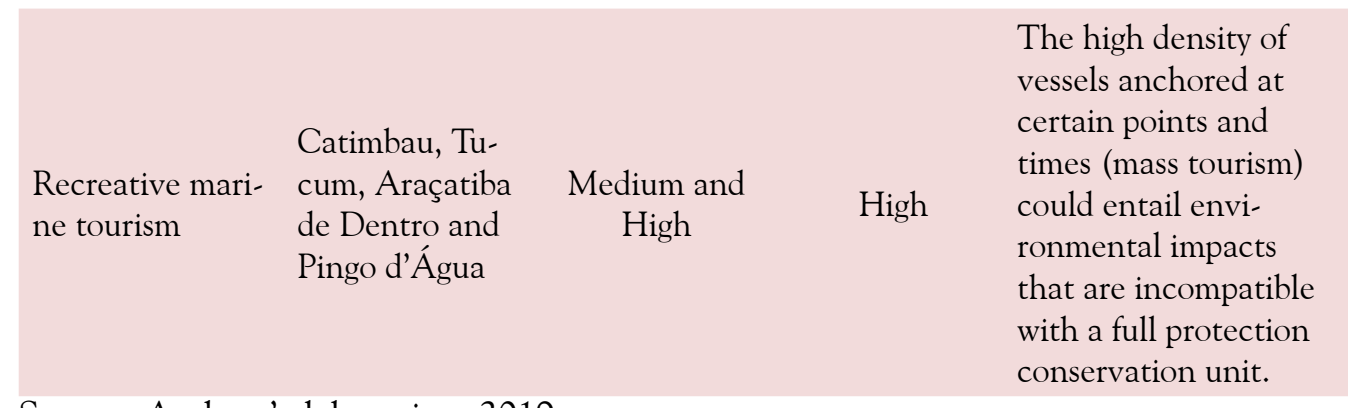

Source: Authors' elaboration, 2019.

Distribution of uses in the ESEC over time

The spatio-temporal distribution of activities can be appreciated in Figure 3, where the greater intensity of uses in groups 4 (Pingo d'Agua, Tucum de Dentro and Tucum) and 8 (Palmas, Ganchos and Catimbau) are apparent.

\section{Figure 3 - Distribution of the average number of activi- ties observed by year and island grouping}

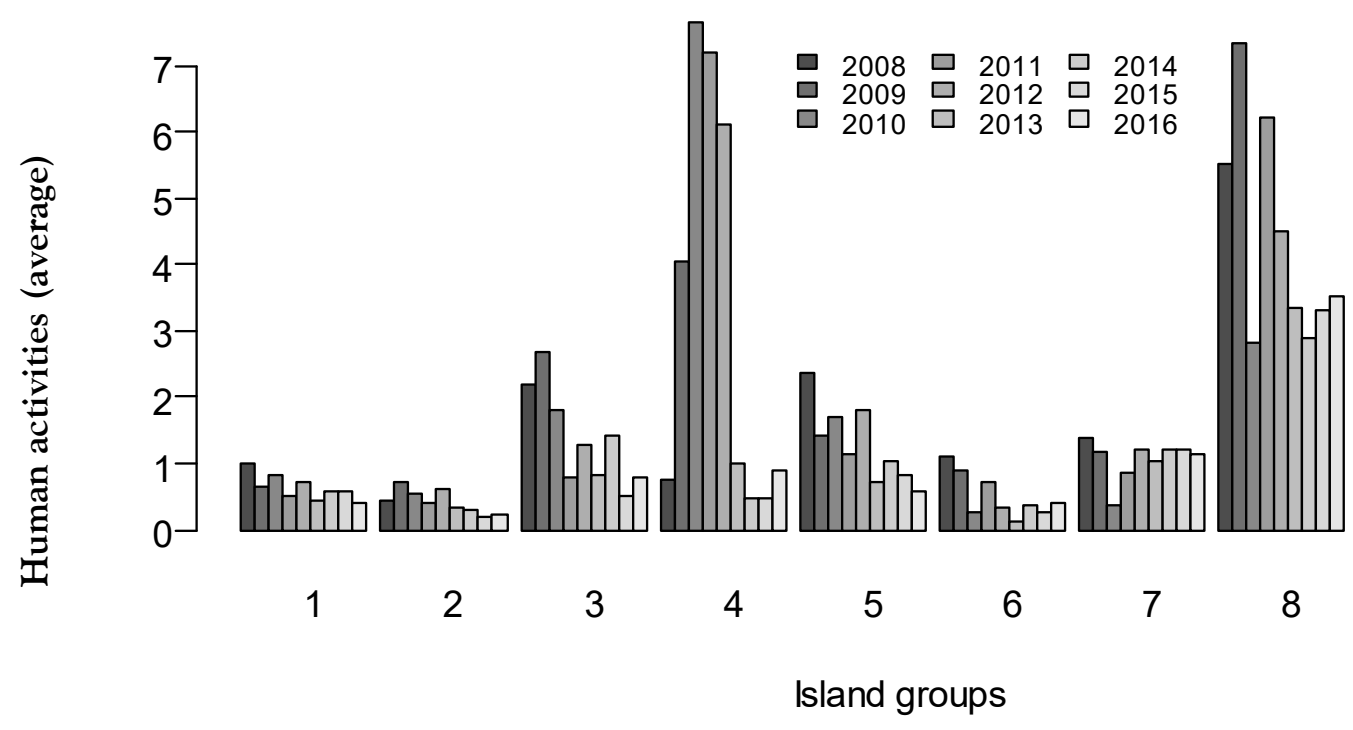

Source: Authors' elaboration, 2019.

Legend: Island groupings, 1 = Imboassica, Queimada Grande, Queimada Pequena; 2 = Zatin, Cobras, Búzios, Búzios Pequena, Laje, Pedra Pelada; 3 = Araçatiba de Dentro, Araçatiba de Fora, Sabacu; 4 = Pingo d'Agua, Tucum de Dentro, Tucum; 5 = Algodão; Sandri; Samambaia; 6 = Araraquara, Araraquarinha, Jurubaíba, Rochedo de São Pedro; 7 = Ilha Comprida, Ilhota Grande, Ilhota Pequena, Laje do Cesto; $8=$ Palmas, Ganchos, Catimbau. 
The ANOVA analysis performed with the data pertaining to all activities registered per year revealed a significant drop in the last four years of monitoring $(p<0.05)$. The average number of activities per trimester varied between 3.5 and 5 in the first four years of sample data, while in the last four years these figures varied between 2 and 2.5 per trimester.

The decrease in total activities observed in the last 4 years is particularly linked to the drop in tourist activities observed from 2013 onward $(p<0.05)$. No significant difference was observed in fishing and traffic activities $(p>0.05)$, although lower values could be appreciated throughout the sampled years.

Upon analyzing the main activities separately with relation to the factor of time, a decrease was noted in most activities in the last four years of monitoring data. The exception to this tendency was anchored tourist vessels, with registries of this activity slightly increasing in the last 2 years.

The ANOVA models performed to assess the possible influence of the seasons on anthropic uses in the Tamoios ESEC revealed that none of the activity categories were associated with a given season. In other words, activities took place in a similar fashion throughout all seasons of the year $(p>0.05)$. Granted, greater occurrences were noted for all activities, tourist activities and fishing activities in the summer, but the values registered were not significantly greater than those of other seasons.

\section{DISCUSSION}

\section{Space-time variation of activities}

The frequency of uses predominantly associated with the category of tourism and recreation - which includes sports - (54\% of all uses) was expected for this region. The Costa Verde is a pre-eminently attractive destination for tourists and has a recognized capacity to drive domestic and international tourism (SEA/INEA, 2015). Angra dos Reis and Paraty are among the ten most sought-out destinations in Brazil (SNPT/MTur, 2013). The registries of vessel traffic (25\% of total) are the result of the heavy navigation in the area's maritime space. Fishing activities, despite their considerable relevance within the Bay of Ilha Grande (FIPERJ, 2013), occurred less (21\% of total). This may be attributed to several factors: the deployment of awareness initiatives on the existence of the ESEC and its corresponding borders (ICMBio, 2015); the participation of fishers in discussions on the Tarituba Term of Commitment (DIAS; SEIXAS, 2019); or to insufficient surveying of fishing vessels which, as indicated by ICMBio (2009), are predominantly active at night.

The great spatial variation of the data analyzed as per the categorical variables of interest (islands groupings) in the Tamoios ESEC may have occurred due to the unit's characteristics, such as the large number of islands and the discontinuous and dispersed delimitation in the Bay of Ilha Grande, which makes it more susceptible to a wide variety of human interference.

The decrease in tourist and recreational uses, observed mainly in the last four 
years of monitoring, could be the result of improvements in the management process. Application of the CU Management Plan via communication measures (information signs, messaging at events and greater institutional presence in the area), as clarified in the ICMBio's reports $(2015,2016 \mathrm{a})$, may have helped to achieve greater awareness among society to recognize the area as a conservation unit and acknowledge its restrictions. Periodic routine efforts to monitor human activities also serve the purpose of informing the area's users and spreading awareness. However, the findings reveal that these actions did not contribute to any general decrease in fishing activities. Artisanal fishers' resistance to "losing" their fishing territories could be related to their bond with the locations where they carry out their trade and/or uphold cultural values, as this method of fishing offers limited autonomy. Despite the possibility for artisanal fishers to take part in other activities such as agriculture or tourism, fishing provides a significant contribution to household income and to the social economy of the Bay of Ilha Grande (IBIO, 2009).

Time-related variations in anthropic activities are commonly influenced by factors such as seasonality, holiday periods and climate conditions-particularly in the case of tourist and recreation activities (HIGHAM; HINCH, 2002; FERNANDEZ-MORALES, 2003; JANG, 2004).While seasonality is one of tourism's most significant characteristics (HIGHAM; HINCH, 2002), no seasonal pattern was observed in relation to any of the activity categories (tourism, traffic or fishing). This could be explained by the dynamics of the Bay of Ilha Grande where, in general, climatic variations are not observed throughout the year. In addition, the Bay of Ilha Grande's sheltered waters provide favourable conditions for navigation, thus accommodating the passage of vessels and consequent anthropic uses in the region all year round. This finding reaffirms that monitoring measures, awareness campaigns and inspections should take place throughout the entire year.

\section{Guidance for management priorities}

The greater occurrence of human activities registered in the marine areas pertaining to the islands Catimbau, Araçatiba de Dentro, Ilha Comprida, Sandri and Tucum are indicative of the need for greater effort and guidance in these areas to prevent irregularities from occurring there.

Although the lowest number of human activities were registered in the marine areas of island groupings 2 and 6 , those uses were mostly related to fishing. This category activity has the greatest impact compared to the others registered in the Tamoios ESEC (CARDOSO, 2019). Thus, while there is a low quantitative number of occurrences in this area, management measures including inspections should be reinforced to mitigate conflicts related to fishing. Artisanal fishing represents $93 \%$ of the fishing methods used in Paraty and 40\% of those in Angra dos Reis (FIPERJ, 2019). In light of this, containment measures should be given priority for large-scale commercial fishing in the marine area pertaining to the municipality of Angra dos Reis. The restrictions linked to the area being protected mainly affect the caiçara residents, who face barriers to practising other types of fishing (BEGOSSI, 2010).

The decrease in human activities observed over time was probably the result of 
management measures linked to increased information, signage, weekly monitoring and inspection operations. However, as the findings show, these measures lacked scale, targeting efforts and thoroughness owing to structural issues. Basic, relatively simple measures such as signage (installing signs on the islands and in continental areas) and maritime signage (installing buoys to mark the ESEC's borders) are essential. So too are informative measures on the CU's very existence, the area and borders of which are discontinuous and not clearly defined. In general, effective management of CUs entails a series of constant difficulties such as a lack of trained technical staff, financial resources and adequate infrastructure (RYLANDS; BRANDON, 2005; ARAÚJO, 2007; RODRIGUES et al., 2019).

\section{Alternative activities and uses}

Heavy usage in specific locations of MPAs can lead to potential conflicts, although recognition of such as a conflict is highly dependent on the nature of the related activities (BECKLEY et al., 2010). In the case of the Tamoios ESEC, the intense restrictions associated with its category lead to a high rate of conflictive spots in this CU. While certain adaptive management measures exist and are important to help alleviate such conflicts, the possibility of applying them are limited. Examples of sustainable activities that could take place under certain limitations, provided they adapt to the goals of an Ecological Station, include artisanal fishing, small-scale mariculture of native species and ecological tourism for educational purposes.

Although only a small number of activities associated with artisanal fishing were registered, the relationship between the fisher community and the management body is conflictive since these parties have diverging interests as relates to the use of marine space. Several studies have analyzed the conflicts surrounding the implementation of the Tamoios ESEC in areas traditionally used by the artisanal fishers of Tarituba. Those studies have highlighted the importance of more participative and conciliatory approaches to managing MPAs in order to effectively meet the objectives of protecting and conserving their ecosystems (LOPES et al., 2013, 2015; DE FREITAS, 2014; SEIXAS et al., 2017; JOVENTINO; FORMIGA-JOHNSSON, 2018; DIAS; SEIXAS, 2019). Management must be attentive to such matters, using relevant instruments to mitigate conflict such as Terms of Commitment or proposals to review limitations via participatory processes that seek to minimize social damages in the affected communities. In Paraty, Lopes et al. (2013) indicated that changes to the MPAs' design, implemented through processes incorporating the use and knowledge of fishers, likely reduced conflict between fishers and enforcement agencies.

In an attempt to acknowledge the effects of the protected area on the fisher community of Tarituba (Paraty) and to sanction subsistence fishing in some of the unit's marine areas, a Term of Commitment was adopted in 2017 with the community (ICMBio, 2017a).It is considered that this can be an effective conciliatory instrument and, to a certain extent, can contribute to minimizing damages in the affected community. The opportunities created through this process led to greater awareness among the different interested parties regarding the role of fishers in governance, environmental conservation 
and community administration. Nonetheless, a range of challenges still remain to achieve a more participative management approach (DE FREITAS et al., 2017; SEIXAS et al., 2017; DIAS; SEIXAS, 2019).

Delimiting areas with relevant environmental attributes to establish ecological tourism could be an effective alternative to the recreational tourism practised in the unit. The aim of which would be to reconcile tourist visitation and the conservation of natural areas through environmental education. Since navigation is allowed in the Tamoios ESEC, contemplative tourism (watching) could be promoted and regulated. Lopes et al. (2015) indicate that a synergic relationship can be reached between tourism, fishing and MPAs. Those authors observed that fishers involved in tourist activities outside the ESEC had better hauls than those who focused solely on fishing. Moreover, eco-tourism can be considered a concrete possibility to combine conservation with efforts to reinforce the culture of resident communities (LAYRARGUES, 2004). Including residents in the management of protected areas would represent an alternative for these areas to contribute to regional development, generating economic and socio-environmental benefits both for CUs and the receiving communities (STRONZA; GORDILLO, 2008). It is considered that eco-tourism promoting sustainable development contributes to achieving one of the main goals of the National Conservation Units System in these protected areas (BOTELHO; RODRIGUES, 2016).

Efficient management of the unit allows important ecosystem conservation goals to be met since, beyond contributing to maintaining and recovering fish stocks in the bay (PAULY et al, 2002; PAULY et al., 2005; YE et al., 2013; SCHILLER et al., 2018), it provides a habitat for endangered species such as the grey nose dolphin, grouper species, the seahorse and the sea cucumber (ICMBio, 2016b).

It is important to highlight the important role played by the Tamoios ESEC in providing ecosystem services. Despite the socio-environmental conflicts surrounding its existence, the CU encompasses merely 5.69\% of the Bay of Ilha Grande. If combined with management initiatives and targeted efforts regulating the occupation of the marine area, sustainable activities such as mariculture of native species, artisanal fishing and ecological tourism could stand to benefit from a regulated Bay of Ilha Grande.

\section{Conclusion}

Understanding the spatial distribution and intensity of anthropic uses allowed the authors to identify more conflictive areas in the CU requiring priority efforts on the part of management, such as the islands of Catimbau, Araçatiba de Dentro, Tucum, Sandri and Ilha Comprida. However, management would also do well to pay greater attention to the prevalence of fishing activities despite their low number of occurrences in some areas. Indeed, the diverging interests between these uses (fishing vs. conservation) embody one of the region's main socio-environmental conflicts.

This being the case, this study recognizes the need for the Tamoios ESEC to continue to exist given its environmental characteristics, which are extremely relevant for 
conservation and invaluable to maintain the environmental health of the Bay of Ilha Grande. This area is unique and does not yet suffer from a high rate of environmental degradation like the State of Rio de Janeiro's other two bays (MOLISANI et al., 2004; SOARES-GOMES et al., 2016).

Furthermore, acknowledging that this $\mathrm{CU}$ is affected by the influence of diverse types of human activities, the authors offer evidence that it is possible to reconcile ecological protection with uses which are not as incompatible and involve social vulnerability. For example, in the case of artisanal fishing, which existed prior to the creation of the $\mathrm{CU}$, instruments provided for in the current legislation, such as Terms of Commitment, are recommended as a means to achieve reconciliation with the mandate to ensure ecological protection. Moreover, the authors highlight that greater efforts are required from management to reduce and control uses that are highly incompatible with the $\mathrm{CU}$, e.g. industrial fishing and mass tourism.

For future works, it is recommended to rethink the sample design behind human activity monitoring to provide evidence of certain hypotheses: that more activities occur on weekends, that peaks occur in the high season (holidays) and that the most highimpact activities (industrial fishing) occur at night.

In the prevailing context of environmental politics, wherein the Tamoios ESEC is under attack and some suggest that it should be dissolved (BRAGANÇA, 2019), identifying and understanding which activities take place in the CU is increasingly relevant. Such information is essential to assist future decision-making and to create more efficient administrative protocols for the management and conservation of this marine protected area. This study, in addition to others focusing on this region, provide major elements for a more strategic management approach. These include possibly redrawing the unit's borders (to replace areas with well-established human activities by more ecologically relevant areas) making management processes more participative, and incorporating conflict management as relates to certain uses, without downplaying the need to uphold the ecosystem services currently provided.

\section{ACKNOWLEDGEMENTS}

Part of the research for this paper was financially supported by Coordenação de Aperfeiçoamento de Pessoal de Nível Superior - CAPES. Special thanks to Tamoios Ecological Station (ESEC Tamoios) for providing the necessary data related to human activities monitoring and for supporting the development of this research. We also thank Conselho Nacional de Desenvolvimento Científico e Tecnológico (CNPq), and Colin Brown for translating this article into English. 


\section{REFERENCES}

ACSELRAD, H.; BEZERRA, G. N. Inserção econômica internacional e "resolução negociada" de conflitos ambientais na América Latina. In: ZHOURI, A. LASCHEFSKI, K. (org.). Desenvolvimento e conflitos ambientais. Belo Horizonte: Editora UFMG, 2010. p. 35-62.

AGARDY, T.; BRIDGEWATER, P.; CROSBY, M.; DAY, J.; DAYTON, P.; KENCHINGTON, R. et al. Dangerous targets? Unresolved issues and ideological clashes around marine protected areas. Aquatic Conservation: Marine and Freshwater Ecosystems, v. 13, n. 4, p. 353-367, 2003.

AGARDY, T. Information needs for marine protected areas: scientific and societal. Bulletin of Marine Science, v. 66, n. 3, p. 875-888, 2000.

ALTINO, L. Unidade ambiental que bolsonaro quer transformar em Cancun obrigatória para funcionamento de usina nuclear. O Globo, 19 de maio de 2019. Disponível em: https://oglobo. globo.com/rio/unidade-ambiental-que-bolsonaro-quer-transformar-em-cancun-obrigatoria-para-funcionamento-de-usina-nuclear-23670678. Acesso em 20 de maio de 2019.

ANGULO-VALDÉS, J. A.; HATCHER, B. G. A new typology of benefits derived from marine protected areas. Marine Policy. v. 34, n. 3, p. 635-644, 2010.

ARAÚJO, M. A. R. Unidades de conservação no Brasil: da República à gestão de classe mundial. Belo Horizonte: Segrac, 2007.

ASSIS, C. C. de. Controle da visitação pública nas piscinas naturais da Costa dos Corais em Maragogi (AL). Revista Brasileira De Ecoturismo (RBEcotur), v. 4, n. 4, 2011. https:/doi. org/10.34024/rbecotur.2011.v4.6023

BAN, N.; ALDER, J. How wild is the ocean? Assessing the intensity of anthropogenic marine activities in British Columbia, Canada. Aquatic Conservation: Marine and Freshwater Ecosystems v. 18, n. 1, p. 55-85, 2008.

BECKLEY, L. E.; SMALLWOOD, C. B.; MOORE, S. A.; KOBRYN, H. T. Spatio-temporal distribution of recreational usage in Ningaloo Marine Park, north-western Australia: A synoptic overview. p. 24-45. In: Human use of Ningaloo Marine Park. Australia: Commonwealth Scientific and Industrial Research Organization (CSIRO), 2010.

BEGOSSI, A.; LOPES, P.F.; OLIVEIRA, L.E.C.; NAKANO, H. Ecologia de Pescadores Artesanais da Baía de Ilha Grande. São Carlos: RiMa Editora, FAPESP. 2010. 298 p.

BOTELHO, E.S.; RODRIGUES, C. G. O. Inserção das iniciativas de base comunitária no desenvolvimento do turismo em parques nacionais. Caderno Virtual de Turismo, v. 16, n. 2, p. 280-295, 2016.

BRAGANÇA. D. "Por que tem que ter lá uma estação ecológica?", diz Bolsonaro sobre Tamoios. O ECO. 20 de maio de 2019. Disponível em: https://www.oeco.org.br/noticias/por-que-tem-que-ter-la-uma-estacao-ecologica-diz-bolsonaro-sobre-tamoios/ Acesso em: 23 de maio de 2019. 
BRASIL. Decreto n. 84.973, de 29 de julho de 1980. Dispõe sobre a co-localização de Estações Ecológicas e Usinas Nucleares. Diário Oficial de Brasília, DF, 29 jul. 1980, Seção 1, p.15195.

. Decreto n. 98.864, de 23 de janeiro de 1990. Cria a Estação Ecológica de Tamoios. Diário Oficial da União, Brasília, DF, 24 jan. 1990, Seção 1, p.1714.

. Lei Federal no 9.985, de 18 de julho de 2000. Institui o Sistema Nacional de Unidades de Conservação da Natureza. Brasília, DF, 2000. Seção 1, p. 1.

CARDOSO, C. D. P. Análise das atividades humanas na Estação Ecológica de Tamoios-RJ como subsídios para uma gestão estratégica. 2019.152f. Tese (Doutorado em Meio Ambiente) - Universidade do Estado do Rio de Janeiro, Rio de Janeiro, 2019.

CRAIN, C.M.; KROEKER, K.; HALPERN, B.S. Interactive and cumulative effects of multiple human stressors in marine systems. Ecology Letters, v.11, n. 12, p. 1304-1315, 2008.

CREED, J.; JUNQUEIRA, A.; FLEURY, B.; MANTELATTO, M.; OIGMAN-PSZCZOL, S. The Sun-Coral Project: the first social-environmental initiative to manage the biological invasion of Tubastraea spp. in Brazil. Management of Biological Invasions. v. 8, p. 181-195, 2017.

CREED, J.C.; PIRES, D.O.; FIGUEIREDO, M.A. de (Orgs). Biodiversidade Marinha da Baía da Ilha Grande. Brasília-DF: MMA/SBF, 416p., 2007.

DE FREITAS, R.R. 2014. Implicações de políticas de conservação e desenvolvimento na pesca artesanal costeira em uma área marinha protegida da Baía da Ilha Grande. Tese (Doutorado em Ambiente e Sociedade), Instituto de Filosofia e Ciências Humanas, Universidade Estadual de Campinas, Campinas, SP. 2014.

DE FREITAS, R.R.; CHAMY, P.; DUMITH, R. C. Institutional design of small-scale fisheries in marine protected areas applied to sustainable territorial development on the Brazilian coast. Ocean \& Coastal Management., v.139, p.92 - 101, 2017.

DIAS, A.C.E.; SEIXAS, C.S. Delineamento Participativo do Protocolo de Monitoramento da Pesca Artesanal da comunidade de Tarituba, Paraty, RJ. Ambiente \& Sociedade, v. 22, p 1-24, 2019.

DIEGUES, A. O mito moderno da natureza intocada. São Paulo: NUPAUB - Núcleo de Apoio à Pesquisa sobre Populações Humanas e Áreas Úmidas Brasileiras - USP/Hucitec, 2001.

EDGAR G.J.; STUART-SMITH R.D.; WILLIS T.J.; KININMONTH S.; BAKER S.C.; BANKS S. et al. Global conservation outcomes depend on marine protected areas with five key features. Nature. v. 506, p. 216-220, 2014.

FERNANDEZ-MORALES, A. Decomposing seasonal concentration. Annals of Tourism Research. v. 30, n.4, p. 942-956, 2003.

FIPERJ. Fundação Instituto de Pesca do Estado do Rio de Janeiro. Diagnóstico da Pesca do Estado do Rio de Janeiro. Projeto de Monitoramento da Pesca no Estado do Rio de Janeiro - 
Estatística Pesqueira. Niterói, RJ: FIPERJ, Convênio SEAP/PR 041/2008, 2013, 108 p.

FIPERJ. Fundação Instituto de Pesca do Estado do Rio de Janeiro. Projeto de monitoramento da atividade pesqueira no Estado do Rio de Janeiro PMAP-RJ. Relatório técnico semestral - RTS03 PMAPRJ_BR_04033027/19.2019, 257 p.

HALPERN, B.S.; MCLEOD, K.L.; ROSENBERG, A.A.; CROWDER, L.B. Managing for cumulative impacts in ecosystem-based management through ocean zoning. Ocean and Coastal Management, v.51, n.3, p. 203-211, 2008 b.

HALPERN, B.S.; WALBRIDGE, S.; SELKOE, K.A.; KAPPEL, C. V.; MICHELI, F.; D'AGROSA, C. et. al. A global map of human impact on marine ecosystems. Science v. 319, n. 5865, p. 948952, 2008a.

HIGHAM, J.; HINCH, T. Tourism, sport and seasons: the challenges and potential of overcoming seasonality in the sport and tourism sectors. Tourism Management. v. 23, n.2, p. 175-185, 2002.

IBAMA. Plano de Manejo da Estação Ecológica de Tamoios. Fase I. Brasília: Instituto Brasileiro do Meio Ambiente e dos Recursos Naturais Renováveis, 2000. Disponível em: http:// www.icmbio.gov.br/portal/component/content/article?id=2254:esec-de-tamoios, último acesso em 27/05/19.

INSTITUTO BIOATLÂNTICA (IBio). Síntese baseada no Relatório do Diagnóstico Socioambiental das Comunidades de Pescadores Artesanais da Baía da Ilha Grande (RJ). Begossi, A.; Lopes, P. F., Oliveira, L. E. C. e Nakano, H. - Rio de Janeiro: Instituto BioAtlântica, 2009.

ICMBio, Instituto Chico Mendes para a Conservação da Biodiversidade. Relatório - Um ano de monitoramento das atividades humanas em áreas da Estação Ecológica de Tamoios. A. N. Gomes e R. P. Lima. Paraty/RJ. 65pp, 2009.

. Relatório de Gestão: Exercício de 2015. Paraty/RJ. 63 p. 2015. Disponível em: http:// www.icmbio.gov.br/esectamoios/publicacoes.html. Útimo acesso em: 26/05/2019.

. Relatório de Gestão: Exercício de 2016. Paraty/RJ. 63 p. 2016a. Disponível em: http:// www.icmbio.gov.br/esectamoios/publicacoes.html. Útimo acesso em: 26/05/2019.

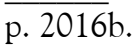

Sumário Executivo da Fauna Brasileira Ameaçada de Extinção. ICMBio, Brasília. 76

. Relatório de Gestão: Exercício de 2017. Paraty/RJ. 54 p. 2017a. Disponível em: http:// www.icmbio.gov.br/esectamoios/publicacoes.html. Útimo acesso em: 26/05/2019.

. Relatório Diagnóstico Continental-Costeiro das Áreas Marinhas da Estação Ecológica de Tamoios: Estruturas Artificiais Instaladas. Adriana N. Gomes \& Graziela M. Barros; Paraty/RJ. 69 p. 2017b. Disponível em: http://www.icmbio.gov.br/esectamoios/publicacoes.html. Último acesso em: 26/05/2019.

JANG, S. Mitigating tourism seasonality: a quantitative approach. Annals of Tourism Research 
v.31, n.4, p. 819-836, 2004

JONES, K.R.; KLEIN, C.J.; HALPERN, B.S.; VENTER, O.; GRANTHAM, H.; KUEMPEL, C.D. et. al. The Location and Protection Status of Earth's Diminishing Marine Wilderness. Current Biology, v.28, n. 15, p. 2506-2512, 2018.

JOVENTINO, F.K.P. Pesca artesanal na Baía de Ilha Grande, RJ: conflitos e novas possibilidades de gestão compartilhada. 2013. Tese de Doutorado em Meio Ambiente, Universidade do Estado do Rio de Janeiro.

JOVENTINO, K.P.; FORMIGA-JOHNSSON, R.M. Conflitos socioambientais envolvendo a pesca artesanal na Baía de Ilha Grande, Rio de Janeiro. Revista Pós-Ciencias Sociais, v. 15, p. 169-196, 2018.

LAYRARGUES, P.P.A. Função social do ecoturismo. Boletim Técnico do SENAC, v. 30, n. 1, p. 1-5, 2004.

LOPES, P.F.M.; PACHECO, S.; CLAUZET, M.; SILVANO, R.A.M.; BEGOSSI, A. Fisheries, tourism, and marine protected areas: Conflicting or synergistic interactions? Ecosystems Service. v. 16, p. 333-340, 2015.

LOPES, P.F.M.; ROSA, E.M.; SALYVONCHYK, S.; NORA, V.; BEGOSSI, A. Suggestions for fixing top-down coastal fisheries management through participatory approaches. Marine Policy, v. 40, p. $100-110,2013$.

MMA. Portaria MMA no 463/2018, 2ª Atualização das Áreas Prioritárias para Conservação da Biodiversidade 2018-. Brasília, MMA.

MOLISANI, M.M.; MARINS, R.V.; MACHADO, W.; PARAQUETTI, H.H.M.; BIDONE, E.D. LACERDA, L.D. Environmental changes in Sepetiba Bay, SE Brazil, Regional Environmental Change, v. 4, p. 17-27, 2004.

MURRAY, C.C.; AGBAYANI, S.; BAN, N. C. Cumulative effects of planned industrial development and climate change on marine ecosystems. Global Ecology and Conservation, v. 4, p. 110-116, 2015.

PARRAVICINI, V., ROVERE, A., VASSAllO, P., MICHELI, F., MONTEFALCONE, M., MORRI, C. et al. Understanding relationships between conflicting human uses and coastal ecosystems status: a geospatial modeling approach. Ecological Indicators. v. 19, p. 253-263, 2012.

PAULY, D.; CHRISTENSEN, V.; GUÉNETTE, S.; PITCHER, T.; SUMAILA, U.R.; WALTERS, C. J. et al. Towards sustainability in world fisheries. Nature, v. 418, n. 6898, p. 689-695, 2002.

PAULY, D.; WATSON, R.; ALDER, J. Global trends in world fisheries: impacts on marine ecosystems and food security.Philosophical Transactions of the Royal Society B: Biological Sciences, v. 360, n. 1453, p. 5-12, 2005. 
PEREIRA, D. B. Paradoxos do papel do Estado nas unidades de conservação. In: ZHOURI, Andréa; LASCHEFSKI, Klemens; PEREIRA, Doralice Barros (Orgs.). A insustentável leveza da política ambiental: desenvolvimento e conflitos socioambientais. Belo Horizonte: Autêntica, 2005. P. 119-142.

POMEROY, R.S.; WATSON, L.M.; PARKS, J.E.; CID, G.A. How is your MPA doing? A methodology for evaluating the management effectiveness of marine protected areas. Ocean $\&$ Coastal Management, v. 48, n. 7, p. 485-502, 2005.

QUINN, G.P.; KEOUGH, M.J. Experimental Design and Data Analysis for Biologists. Cambridge University Press. 2002.

ROCHA, T.C.F; ROLIM, H.N, IKEMOTO, S.M. Um modelo de gestão integrada para a Zona Costeira do Estado do Rio de Janeiro: o projeto gestão integrada do ecossistema da Baía da Ilha Grande (Projeto BIG). Governança para os serviços ecossistêmicos das costas e oceanos II Congresso Ibero Americano de Gestão Integrada de Áreas Litorais, 2016.

RODRIGUES, J.G.V.; MOREIRA, S.A.; FREIRE, E.M.X. Entraves à efetivação de Unidades de Conservação: Parque Estadual Mata da Pipa, Tibau do Sul - RN - Brasil. Desenvolvimento e Meio Ambiente, v. 46, p. 109-132, 2018.

RYLANDS, A.B.; BRANDON, K. Unidades de conservação brasileiras. Revista Megadiversidade, Brasília, v.1, n.1, p.27-35, 2005.

SASSINE, V. 2019. Bolsonaro diz que vai mudar preservação de área em Angra onde foi multado e transformá-la na 'Cancún brasileira'. O Globo, 08 de maio de 2019. Disponível em: https://oglobo.globo.com/rio/bolsonaro-diz-que-vai-mudar-preservacao-de-area-em-angra-onde-foi-multado-transforma-la-na-cancun-brasileira-23649986. Acesso em 09 de maio de 2019.

SCHILLER, L.; BAILEY, M.; JACQUET, J.; SALA, E. High seas fisheries play a negligible role in addressing global food security. Science Advances, v. 48, 2018.

SEA/INEA. Secretaria de Estado do Ambiente; Instituto Estadual do Ambiente. Diagnóstico do Setor Costeiro da Baía da Ilha Grande: Subsídios à elaboração do Zoneamento Ecológico-Econômico Costeiro. Volume I. Rio De Janeiro. 2015.

SEIXAS, C.S.; DIAS, A.C.E.; DE FREITAS, R.R. Navigating adaptiveco-management in Paraty, Brazil: winds, turbulence, andprogress. In: Charles, T. Armitage, D.; Berkes, F. Governing the Coastal Commons: Communities, Resilience and Transformation. The Hague: Routledge, p.157-180, 2017.

SNPT/MTur. Secretaria Nacional de Políticas de Turismo; Ministério do Turismo. Anuário Estatístico de Turismo - 2013 - Volume 40 - Ano base 2012, Brasília, DF: Ministério do Turismo, 2013. $223 \mathrm{p}$.

SOARES-GOMES, A., DA GAMA, B.A.P., BAPTISTA-NETO, J.A., FREIRE, D.G., CORDEIRO, R.C., MACHADO,W. et al. An environmental overview of Guanabara Bay, Rio de Janeiro. Regional Studies in Marine Science, v. 8, n. 2, p. 319-330, 2016. 
STACHOWITSCH, M. Research on intact marine ecosystems: A lost era. Marine Pollution Bulletin. v. 46, n. 7, p. 801-805, 2003.

STRONZA, A.; GORDILLO, J. Community views of ecotourism. Annals of Tourism Research. v. 35. p. 448-468, 2008.

TEIXEIRA-NEVES T.P; NEVES L.M.; ARAÚJO F.G. Hierarchizing biological, physical and anthropogenic factors influencing the structure of fish assemblages along tropical rocky shores in Brazil. Environmental Biology of Fishes, v. 98, p. 1645-1657. 2015.

TUKEY, J. W. Exploratory Data Analysis, Reading, Mass.: Addison-Wesle, 1977.

VALLEJO, L.R. Tempo, espaço e contradições na proteção das áreas naturais: As políticas públicas e a conservação ambiental no Estado do Rio de Janeiro (1975 a 2002). Niterói: Editora Alternativa, 224 p. 2017.

VIVACQUA, M.; VIEIRA, P. F. Conflitos socioambientais em Unidades de Conservação. Política \& Sociedade, Florianópolis, v.4, n.7, p. 139-162, 2005.

WORM, B.; HILBORN, R.; BAUM, J.; BRANCH, T.; COLLIE, J.; COSTELLO, C. et al. Rebuilding Global Fisheries. Science, v. 325, p. 578-585, 2009.

YE, Y.; COCHRANE, K.L.; BIANCHI, G.; WILLMANN, R.; MAJKOWSKI, J.; CAROCCI, M.T.F. 2012 Rebuilding global fisheries: the world summit goal, costs and benefits. Rebuilding global fisheries: the World Summit Goal, costs and benefits. Fish and Fisheries, v.14, n. 2, p. 174-185, 2013.

ZAPPES, C.A.; GATTS, C.E.N.; LODI, L.; ANDRIOLO, A.; DI BENEDITTO, A.P.M. Interações entre o golfinho-nariz-de-garrafa (Tursiopstruncatus) e a pesca artesanal no Arquipélago das Cagarras e áreas adjacentes, Rio de Janeiro, Brasil. Sitientibus. Série Ciências Biológicas, v.11, n.1, p. 24-30, 2011. 
Carolina Delfante de Pádua Cardoso

$\square$ carolcard@gmail.com

ORCiD: https://orcid.org/0000-0002-4883-9900
Submitted on: 16/07/2019

Accepted on: 22/05/2020

2020;23:e01122

\section{Rosa Maria Formiga-Johnsson}

$\square$ rosa.formiga@eng.uerj.br

ORCiD: https://orcid.org/0000-0003-2047-9912

\section{Régis Pinto de Lima}

$\square$ regispintolima@gmail.com

\section{Rodrigo de Oliveira Campos}

$\square$ rodrigocam@gmail.com

ORCiD: https://orcid.org/0000-0001-8078-771X

How to cite: CARDOSO, C. D. P.; FORMIGA-JOHNSSON, R. M.; LIMA, R. P.; CAMPOS, R. O. Monitoring human activities in the Tamoios Ecological Station - Rio de Janeiro: management challenges. Ambiente $\&$ Sociedade. São Paulo, v. 23, p. 1-22, 2020. 


\title{
Monitoramento das Atividades Humanas na Estação Ecológica de Tamoios - RJ: Desafios para a Gestão
}

\author{
Carolina Delfante de Pádua Cardoso \\ Rosa Maria Formiga-Johnsson \\ Régis Pinto de Lima \\ Rodrigo de Oliveira Campos
}

São Paulo. Vol. 23, 2020

Artigo Original
Resumo: Este estudo objetivou compreender a dinâmica de usos antrópicos na área marinha da Estação Ecológica (ESEC) de Tamoios, de modo a oferecer subsídios para gestão e mitigação de conflitos. A partir do registro de atividades humanas em 330 saídas de monitoramento entre 2008 e 2016, este trabalho analisou o conjunto de dados sobre turismo, tráfego e pesca por meio da aplicação de modelos exploratórios de análise de variância unifatorial. A compreensão da distribuição espacial e temporal das atividades humanas, bem como a intensidade de sua ocorrência nos permitiu indicar as áreas mais conflituosas da unidade de conservação e prioritárias para o fortalecimento da gestão. Concluiu-se serem necessárias medidas mais conciliadoras para atividades tradicionais como a pesca artesanal e outras medidas de gestão para as atividades de alta incompatibilidade com a ESEC, a serem pactuadas entre os atores envolvidos.

Palavras-chave: Áreas Marinhas Protegidas.Usos Antrópicos. Conflitos socioambientais.

Como citar: CARDOSO, C. D. P.; FORMIGA-JOHNSSON, R. M.; LIMA, R. P.; CAMPOS, R. O. Monitoramento das atividades humanas na Estação Ecológica de Tamoios - RJ: desafios para a gestão. Ambiente \& Sociedade. São Paulo, v. 23, p. 1-22, 2020. 


\title{
Monitoreo de las Actividades Humanas en la Estación Ecológica de Tamoios - Rio De Janeiro: Desafíos para la Gestión
}

\author{
Carolina Delfante de Pádua Cardoso \\ Rosa Maria Formiga-Johnsson \\ Régis Pinto de Lima \\ Rodrigo de Oliveira Campos
}

São Paulo. Vol. 23, 2020

Artículo original
Resumen: Este estudio tiene como objetivo comprenderladinámica de usos antrópicos en el área marina de Estación EcológicaTamoios, para ofrecersubsidios para gestión y mitigación de conflictos. Según el registro de actividades humanas en 330 productos de monitoreo entre 2008 y 2016, este trabajo utilizó datos en las categorías de turismo, tráfico y pescamediante la aplicación exploratoria de análisis de factores únicos de modelos de varianza. Comprender la distribución espacial y temporal de las actividades humanas, así como la intensidad de su ocurrencia, nos permitió indicar las áreas más conflictivas de la unidad de conservacióny las prioridades para fortalecer la gestión. Se concluyó que se necesitaban más medidas de conciliación para las actividades tradicionales, como la pesca artesanal y otras medidas de gestión para actividades altamente incompatibles con ESEC, que se acordarán entrelos Actores involucrados.

Palabras-clave: Areas Marinas Protegidas. Usos Antrópicos. Conflictos socioambientales.

Como citar: CARDOSO, C. D. P.; FORMIGA-JOHNSSON, R. M.; LIMA, R. P.; CAMPOS, R. O. Monitoreo de las actividades humanas en la Estación Ecológica de Tamoios - Rio de Janeiro: desafíos para la gestión. Ambiente $\&$ Sociedade. São Paulo, v. 23, p. 1-22, 2020. 